\title{
FIFTY YEARS NILR 1953-2003
}

\section{AS TIME GOES BY - Tempora Mutantur}

According to Professor Maarten Bos, one of the two founding fathers of the Netherlands International Law Review and now its Honorary Editor-in-Chief, the first issue of the Review - then called Nederlands Tijdschrift voor Internationaal Recht - appeared on 12 November 1953, at 11.45 p.m., when a parcel containing 10 copies was delivered to the home address of Judge Bob Erades (1911-1985). ${ }^{1}$ Erades was the other founding father of the Review. At the first meeting of the Board of Editors on 13 June 1953, Erades was made Editor-Secretary, some ten years later followed by his appointment as Editor-in-Chief, a position which he held until 2 September 1985.

On the occasion of the Review's Silver Jubilee, in 1979, Erades took a moment to reminisce. He recounted the first twenty-five years of the Review's existence. ${ }^{2}$ In his article he mentioned the initiative taken by Maarten Bos and himself to found a Dutch periodical devoted to the study of international law. Very modestly, he described the tremendous amount of editorial work which was done by him and the other editors for the first twenty-five volumes of the Review. In 1953, the Professors R.D. Kollewijn (1892-1972), J.H.W. Verzijl (1888-1987) ${ }^{3}$ and L.I. de Winter (1911$1972)^{4}$ joined Erades and Bos in the Board of Editors. The first issue of November 1953 opened with an Introduction written by two of Netherlands most eminent legal scholars, Professor W.J.M. van Eysinga (1878-1961) and Professor E.M. Meijers (1880-1954). They welcomed 'with great pleasure the appearance of a Review which has, as its avowed object, the study of international law in all its ramifications'. They continued by remarking that ' $(\mathrm{t}) \mathrm{o}$-day international law finds itself in a state both of rapid flux and of considerable peril' and that '(a)ttempts to make the international community conform to high standards of law, equity and organization conflict with the efforts of certain Powers to impose their will, replacing legal relations by relations of force'. ${ }^{5}$ These words are, more or less, still relevant to present times!

In its 'Foreword' of the first issue the Board of Editors emphasised that the Review 'intends to be a scientific periodical in which Netherlands jurists - whatever

1. See M. Bos, Judge Erades, in Essays on International \& Comparative Law in Honour of Judge Erades, presented by the Board of the Netherlands International Law Review (The Hague, Nijhoff 1983) p. X.

2. L. Erades, 'The Editor-in-Chief looks back some twenty-five years', 26 NILR (1979) pp. 1-4.

3. A biographical description of life and work of Verzijl and Kollewijn can be found in The Moulding of International Law: Ten Dutch Proponents (The Hague, T.M.C. Asser Institute 1995) pp. 335-398.

4. See L. Erades, In Memoriam L.I. de Winter, 19 NILR (1972) pp. 99-101.

5. See 1 NILR (1953) p. 2. 
their position - will be able to follow the development of both spheres of the law which it is designed to cover, and in which, on the other hand, foreign jurists will be enabled to find contributions made to that development by the Netherlands'. ${ }^{6}$ International law, both public and private, was to be covered, and still is. Initially, the Review published articles in the Dutch language (accompanied with a brief summary either in English or French), as well as articles in English or French. This policy of trilingualism was retained until Volume XXIII(1976), when it was decided to publish henceforth only in the English language. The official title of the Review became Netherlands International Law Review (NILR). ${ }^{7}$ Since 1973, NILR is published in close and fruitful cooperation with the T.M.C. Asser Institute at The Hague, which also holds the Editorial Office. ${ }^{8}$

Two months after his retirement from the Board of Editors, Judge Erades passed away on 6 November $1985 .{ }^{9} \mathrm{He}$ w as suc ceeded by Profess or Bos as Editor-in-Chief. Bos presided the Board Meetings with much eloquence and maintained the highest quality requirements for which NILR stands. On 1 January 1994 Maarten Bos retired from the Board after 40 years of devoted work for NILR. He was succeeded by the present Editor-in-Chief. ${ }^{10}$

The Board considers itself fortunate that NILR was and still is one of the leading journals in the field of international law. From a historical point of view, Dutch lawyers and legal scholars played an important role in the development of international law. The Hague is a prominent centre of international law - 'The Legal Capital of the World' - and hosts many international organisations (e.g. the International Court of Justice, the International Criminal Court, the International Criminal Court for the Former Yugoslavia, the Hague Conference on Private International Law). NILR tries to be a platform for new global developments in the field of international law. It is satisfying to see that authors of all parts of the world find their way to NILR submitting articles for Board approval. How ever, a selective approach by the Board is necessary to meet the quality standards of the Review and to maintain an equilibrium between public and private international law, and, since 1982, also comparative law. Private international law is more dominant in the various features of the Review, namely in the forms of case notes on decisions involving questions of Dutch private international, case law on the EC Jurisdiction and Judgments Regulation, or information offered by the Hague Conference on Private International Law, etc.

In the fifty years of its existence NILR published several special issues. Here mention is made of two special issues in the last decade: in 1992 on the occasion

\footnotetext{
6. See 1 NILR (1953) p. 10

7. See 23 NILR (1976) p. 1.

8. See for the history of the cooperation with the Asser Institute, Erades, op. cit. n. 2, at p. 4.

9. See In Memoriam, 32 NILR (1985) p. 353.

10. See 'Editorial Note', 41 NILR (1994) p. V.
} 
of the celebration of the rediscovery of the Americas, ${ }^{11}$ and in 1993 on the celebration of the centenary of the Hague Conference on Private International Law. ${ }^{12}$ Special issues demand a thorough preparation from the Board as well as the authors invited. To celebrate NILR's fiftieth anniversary, the Board decided to publish a special issue devoted to the time factor in international law. This theme meets with this Golden Jubilee perfectly. Time changes the world, it changes the law and it changes us, or in other words - quoting from Ovid's Metamorphosis (15:165) tempora mutantur.

For this Special Issue the Board invited several authors to write about certain problems in relation to the time element in international law. The Board is very grateful to the authors for their friendly cooperation and their willingness to write about the subject suggested by the Board. The articles published give the reader an overview of a variety of problems relating to the time factor in international law. From 'limping treaties' (Anthony Aust), the declining importance of the travaux préparatoires (Jan Klabbers), reparations for historical injustices (Dinah Shelton) and state responsibility for injurious transboundary activity in retrospect (Nathalie Horbach and Pieter Bekker) to an analysis of problems relating private international law. In this field the articles vary from the evolution of public policy in private international law (Joost Blom), tort and contract jurisdiction via the Internet (Patrick Borchers), the treatment of family unions in private international law (Kurt Siehr) to the impact of time in the recent EC Regulations on international civil procedure (Paul Meijknecht). These contributions demonstrate that time, indeed, goes by. In today's world we are facing new problems for which international law has to create new solutions, but in finding these solutions we ought to learn from solutions made in the past. Time changes and we change. As time goes by is therefore chosen by the Board as an appropriate title for this Special Issue. ${ }^{13}$ The Board expresses the sincere hope that this issue will be interesting to our readers all over the world and that the Review may prosper in the years ahead, contributing - as the Board of Editors wrote in the first issue in 1953 - to a further growth of international law.

Editor-in-Chief

11. Five Hundred Years Since the Rediscovery of the Americas, 39 NILR (1992) pp. 1-266 (issues 1 and 2 of Volume XXXIX were also published separately in bookform by the T.M.C. Asser Institute, The Hague, 1993).

12. The Hague Conference on Private International Law, 40 NILR (1993) pp. IX-142. This Special Issue was also published separately under the title: The Influence of the Hague Conference on Private International Law: Selected Essays to Celebrate the 100th Anniversary of the Hague Conference on Private International Law (Dordrecht, Nijhoff 1993).

13. 'As time goes by' is taken from the famous film Casablanca (1942) with Humphrey Bogart and Ingrid Bergman. 